\title{
The Impact of Professional Learning Communities on English Teacher Belief Change
}

\author{
Zhanwen Song \\ Department of Foreign Languages, Hospitality Institute of Sanya \\ Sanya, Hainan, China \\ Ogunniran Moses Oladele (Corresponding author) \\ Mahatma Gandhi Institute of Education and For Peace and Sustainable \\ New Delhi, India \\ E-mail: ogunniranmoses1985@yahoo.com
}

Received: March 8, 2021

Accepted: April 29, 2021

Published: May 5, 2021

doi:10.5296/ijl.v13i3.18606

URL: https://doi.org/10.5296/ijl.v13i3.18606

\begin{abstract}
This study aimed to examine the impact of professional learning communities on English teacher belief change with English teachers in Hospitality Institute of Sanya as a case study. The study proffered answers to magnitudes at which professional learning communities motivate English teacher belief change in Hospitality Institute of Sanya, the characteristics of professional learning communities that affect English teacher belief change in Hospitality Institute of Sanya, and the belief changes that were experienced by English teachers in Hospitality Institute of Sanya. The study adopted a qualitative research design that used structured interviews with (fifteen) 15 English teachers as participants for the study. Thematic analysis was used to analyze the data. Findings showed that most participants had the right perspectives of their communities through the professional learning communities, which exert positive effects on English teacher belief change. Reflective dialog, feedback among teachers, collaborative activity, a shared sense of purpose, and collective focus on students' learning were found out to be the major characteristics of professional learning communities that affected English teacher belief change in Hospitality Institute of Sanya. The study recommended that teacher belief change needs to be monitored by the institution's authority, going by the nature of the activities that go on in the institution.
\end{abstract}

Keywords: Professional learning community, English teacher belief change 


\section{Introduction}

There is no doubt that professional learning communities are widely varied in terms of practice across different countries. Yet, various professional learning communities do upgrade teachers' skills for better learning outcomes. They also bring about positive change among teachers, especially teacher belief change.

Following the impact of professional learning communities on the belief change of teachers, researchers have studied the positive effect in this area. Bulkley \& Hicks (2005) were of the opinion that teachers must have spent reasonable periods of their time in the classroom where they deal with their regular duties, they paid close attention to this for most periods of their time, yet there are other works also that will affect their belief change. The interaction among teacher colleagues is very important and essential for effective process and better outcomes of teaching and learning, especially in foreign countries. Besides, professional learning communities have become a unique tool in meeting new knowledge and other teachers' requirements. These professional communities of teachers have continuously helped them have the right perspectives of their new environment, which allows both the teachers and the institutions. These professional learning communities have been fulfilling teachers' immediate needs and providing them with the positive function of joint professional learning (Stoll, Bolam, McMahon, Wallace \& Thomas, 2006).

Researchers have suggested that for any reform to be successful in institutions, teacher belief change is a factor to reckon with (Richardson \& Placier, 2001; Grossman, Wineburg, \& Woolworth, 2001). This teacher belief change will create designed activities to enhance the skills and understanding of teachers in a way that will lead to the expected changes in their beliefs, thinking, and characters exhibited in their various classrooms. Attentions have been directly shifted to planned professional learning communities whereby teachers will passively listen to professional colleagues (Clarke \& Hollingsworth, 2002).

Despite that, there is also another perspective on teacher change, which concentrates on foreign teachers as learners and institutions as the learning communities (Clarke \& Hollingsworth, 2002). Professional learning communities are radical changes in the basic assumptions from traditional teacher development to modern teacher. These changes are monitored by professional learning in the institution where teachers share their experiences within their immediate environment (Grossman et al., 2001; Stoll, Bolam, McMahon, Wallace, \& Thomas, 2006).

Earlier research on professional learning communities had concentrated on the characteristics of the member communities (Kruse, Louis \& Bryk, 1995). Vescio, Ross \& Adams (2008) had focused on the factors leading to successful professional learning communities. Wong (2010) examined how professional learning communities enhance effective teaching and better learning outcome. Tam (2014) recently looked into the beliefs and practices by examining the role the professional learning community played in teacher change. None of these researches has delved into English teacher belief change, nor had anyone been done in the Hospitality Institute of Sanya, leaving gaps for this study to fill. Therefore, this study investigates the 
impact of professional learning communities on English teacher belief change: A case study on English teachers in Hospitality Institute of Sanya.

\section{Literature Review}

\subsection{Concept of Professional Learning Communities}

The concept of professional learning communities in school communities may not be new. The professional learning communities in a higher institution like Hospitality Institute of Sanya are a unique concept. The literature on professional learning communities categorizes them as a subset of communities of practice that involve such communities' participants (Lave \& Wenger, 1991). Thus, the actual learning that will then occur in both practice and professional learning communities are expected to be interactive, progresses, and collaborative in achieving the communities' overall objectives. Over the years, professional learning communities have gained a well-known recognition in the international teaching context as what support members and develop a recognized structure that has achieved remarkable improvement in effective teaching and better learning outcomes (McLaughlin \& Talbert, 2006; Darling-Hammond, 2013).

Brodie \& Borko (2016) explained the unique attribute of professional learning communities as the focus of professional learning. These researchers described this professional learning as different forms of learning that support professional member to become more competent and confident in their professional activities. These different forms of learning are drawn from a knowledge base that is specific to a particular profession. In the case of this study, it is English teachers.

Learning is a fundamental part of professional learning communities. This learning is situated among the daily practice of teachers in their institution of learning. Teachers in professional learning communities acquire both learning and development. This acquisition of new and relevant knowledge makes teachers move from a collective and reflective inquiry into better professional teachers. This enables teachers to justify their decisions, thinking, and actions in agreement with their knowledge base (Brodie \& Borko, 2016). Therefore, professional learning communities' role in institutional contexts aims to create a networked community that will provide teachers with continuous assistance. This assistance is to transform their qualities of pedagogy and provide them with the right perspectives.

As several researchers focus on professional learning communities, many of them give their definitions from different perspectives. Scribner, Cockrell, Cockrell \& Valentine (1999) submitted that since the publication of "A Nation at Risk" in 1983, teachers' professionalization and development have become important issues in school development. Learning communities have been defined as places where students and pupils at all levels become active learners. Generally, students and pupils are involved in matters that are unique to them and where they are encouraged to learn (Roberts \& Pruitt, 2008).

Hord, Roussin, \& Sommers (2009) presented their view on professional learning communities as teams that give teachers universal views. This enables teachers to collaborate, share, reflect on their needs to enhance effective teaching and better learning outcomes. The 
concept of professional learning communities in an institution refers to situations where teachers and other staff members follow the following five dimensions steadily: shared values and vision; supportive and shared leadership; supportive conditions, shared personal practice, collective learning, and application of learning. Roberts \& Pruitt (2008) looked into learning communities as a system of culture for members to acquire knowledge in its entirety. This will be helpful to acquire relevant knowledge and other good aspects to interact with other members.

English teachers and all learners of a foreign language will benefit from positively developing learning communities. In the institution where learning community is a continuous procedure, collaborative interactions are expected among English teachers, leaders, students, staff, and parents. These interactions will be achieved through the way of conversation that will develop knowledge acquisition in the institution. The learning community will help all members and make them contribute to the learning community (Roberts \& Pruitt, 2008). Professional learning communities enable teachers to get more fundamental knowledge combining with formal and practice knowledge. Professional learning communities also bring about true contextual and application knowledge by providing relevant conversation and writing that will establish a close relationship among members.

Professional learning communities could be viewed from two perspectives: the first perspective is that these communities help teachers have regular interactions with their professional colleagues, which will increase their knowledge. At the same time, the second perspective is that these communities make teachers plan and discuss the forms, methods of teaching, contents, and all other activities that they observed among their peers. This will give teachers opportunities to research and publish by exploring new knowledge (Fernandez, 2002).

There is another development of how professional learning communities have helped teachers expand their goals and sights. Teachers achieve these by sharing individuals' actions that enable them to build a common culture, which leads to ongoing collaboration in more supportive and knowledgeable manners (Stoll and Seashore Louis, 2007). Professional learning communities give teachers the opportunity to pay more attention to tallow teachers by evaluating their own ideas. Also, McLaughlin \& Talbert (2006) delved into how important is the presence of teachers in connection with others outside classrooms. The researchers concluded that it is not sufficient to assess teachers' classrooms by evaluating and measuring their students' results without looking into their professional learning and development.

Stoll and Seashore Louis (2007) contributed to the concept of professional learning communities in schools by presenting four major key points in understanding the concept. These are professional learning, collective knowledge, the paradigmatic members or team, and creating an atmosphere that will morally take care of teachers, leaders, and students. Meaningful development will be challenging to achieve in any institution without professional learning communities that encapsulate teachers, leaders, students, parents, and other prominent community members. All these stakeholders are expected to appropriately 
engage in dialogs and conversations on related topics that will bring about institutional community development (Roberts \& Pruitt, 2008). Some researchers had also described professional learning communities as a positive environment that allows teachers to interact and work with other professional colleagues to achieve the common goal of student accomplishments through the institution's functioning system (Hord et al., 2009). In response to whether professional learning communities can remain sustainable over time, Stoll et al. (2006) submitted that changes in senior management of the institution are a factor to reckon with. There is, therefore need to pay conscious attention to the potential of management succession planning that will help promote the sustainability of professional learning communities.

\subsection{Professional Learning Communities and English Teacher Belief Change}

Most teachers think that change is described as the teacher's belief related to socialization, growth, learning, development, improvement, implementation of different or new something, affective and cognitive change, and self-study (Richardson \& Placier, 2001). Some researchers like Clarke \& Hollingsworth (2002); Richardson \& Placier (2001) have worked on teacher change, and they confirmed it involved changes in the teacher's behavior and cognition. Cognition of the teacher is a broad term that encapsulates a collection of beliefs, attitudes, images, knowledge, theories, assumptions, perspectives, metaphors, and conceptions. This cognition of teacher also covers teaching, curricula, students, subject matter, teachers, learning, materials, self, and instructional activities (Borg, 2003). Another researcher has also found that change among teachers is expected to acknowledge the significance of beliefs among them. Therefore, it should be designed to provide conditions whereby teachers are expected to reflect on specific questions and explore their beliefs. Teachers will reject any change that is not compatible with their beliefs (Tam, 2005).

Fullan (2007) examines the relationship between teachers' cognition and teachers' beliefs and found out that teachers' cognition and teachers' beliefs are powerful cognitive filters. This power comes through curriculum reforms. Therefore, the decisions that teachers will eventually make in terms of their practices will be implemented, perceived, and altered.

Tam (2012) has worked on teachers' beliefs and found that teachers' beliefs are more effective on teachers' teaching practices than policy, resources, and other related factors. Fullan (2007) also contributes to the study of teachers' beliefs and concludes that teachers' beliefs are extremely difficult to change compared to changes in another field, like teaching strategies and instructional materials. Teachers' beliefs can also be defined as implicit assumptions that teachers have before service or during service about their students, classrooms, learning, and the mastery of subject matter to be taught (Kagan, 1992). Teachers' beliefs are not learned consciously by teachers, but they develop naturally over time by their experiences (Tam, 2010a). Another indicator relevant to teachers' beliefs is teachers' behaviors are defined as teachers' actions to better their students' outcomes. For instance, teachers often adopt different teaching methodology, select relevant instructional materials, coordinate classrooms, creating suitable learning activities that guide student learning, among others (Calderhead, 1996). Teachers' beliefs can be categorized under the implicit variable, while other behaviors can be 
categorized under the observable variable (Clark \& Peterson, 1986). Studies on teacher change have pointed out those teachers' beliefs and teachers' practices are both very important indicators that portray change among teachers in the process of their development (Turner, Warzon \& Christensen, 2011).

Akerson, Cullen, \& Hanson (2009) have identified the mastery of the subject matter as one factor that brings about changes in teachers' beliefs and teachers' practices. Lee (2004) identifies teaching as one factor that brings about changes in teachers' beliefs and teachers' practices. Hollins, McIntyre, DeBose, Hollins \& Towner (2004) identify learning as one factor that brings about changes in teachers' beliefs and teachers' practices. Turner et al. (2011) identify motivation and instruction as major factors that bring about changes in teachers' beliefs and teachers' practices. In contrast, Andrews \& Lewis (2002) identify teachers' image as a major factor that brings about changes in teachers' beliefs and teachers' practices.

Pajares (1992) \& Richardson (1996) have acknowledged the difficulty of change in teachers' beliefs and teachers' practices. Hunzicker (2004) pointed out the several reasons that make teachers resist change and why the researcher identified a lack of motivation as one of them. Beck, Czerniak, \& Lumpe (2000) identified expertise to modify existing curricular materials and fall short of knowledge as factors that make teachers resist change. McLaughlin \& Talbert (2001) and Little (2003) identified avoidance of risk-taking, which is against the current best practices of their profession, as one of the factors that make teachers resist change. Grossman et al. (2001) and Little (2003) identified teachers' attitudes when they shun conflict in their community as one of the factors that make them resist change.

On the other hand, McLaughlin \& Talbert (2006) have identified support and collaboration for professional growth among administrators and their peers as cogent factors that affect teachers' change. Tam (2010b) and Wong (2010) identified the leadership of heads of departments as important factors that influence teachers' change. Besides, Guskey (2002) was of the opinion that teachers are more likely to continue enacting new practices when their students make improvements. Harris \& Jones (2010) also work on professional development and found out that professional learning communities help teachers move from self-professionalism to collective professionalism. This movement facilitates professional teachers to work interdependently rather than an individual. Kaasila \& Lauriala (2010) and Tam (2011) submitted that collegiality, professional collaboration, and developed professional roles contribute positively to teachers' collective efficacy. Hindin, Morocco, Matt, \& Aguilar (2007) also found out that variables like collegiality, professional collaboration, and developed professional roles assist colleagues to explore ways of teaching and new curriculum.

Kruse et al. (1995) and Louis \& Marks (1998) proposed five professional learning communities' attributes. First among the five attributes are reflective dialog. According to these researchers, reflective dialog refers to the magnitude at which teachers engage themselves in professional dialogue about major educational issues. Second, among these five attributes is feedback on instruction. According to these researchers, feedback on instruction refers to teachers' observations of one another's classes with the main objective of 
sending and receiving feedback. Third among these five attributes are collaborative activity. Collaborative activity, according to these researchers, refers to a temporal measure of the degree to which teachers involve in collaborative practices. Fourth among these five attributes is a shared sense of purpose. A Shared sense of purpose, according to these researchers, refers to the rate at which teachers agree with the mission of the institution and the principles that operate in the school. The fifth and last attribute is a collective focus on student learning. Collective focus on student learning, according to these researchers, refers to the collective commitment of teachers to the success of their students.

Although these five attributes of professional learning communities are presented in a parallel manner, yet, all of them can be allocated into two sets: the first set is referred to as shared goal (a shared sense of purpose and collective focus on student learning), and the second set is referred to as learning activities (reflective dialog, feedback on instruction and collaborative activity). Researchers have found out that all these five attributes lead to teacher change (Meirink, Meijer, Verloop, \& Bergen, 2009; Hoekstra, Brekelmans, Beijaard, \& Korthagen, 2009; Turner et al., 2011).

Professional learning communities comprise a strong learning environment for teachers to accommodate their beliefs' change about their teaching and students' learning towards institutional reform (Phillips, 2003). Changes in teachers' beliefs are connected to their classrooms, and these classrooms have become more student-centered for several years. However, few studies have focused on teachers' change in both practices and beliefs under professional learning communities (Vescio et al., 2008). The development of professional learning communities focuses on a process that creates a new structure for the institution (Fullan, 2007). However, the magnitude at which professional learning communities become an effective support structure for teachers' change in professional learning is not well understood (Maloney \& Konza, 2011). Researchers again highlighted that professional learning communities have a significant effect on teaching culture, leading to high teachers' involvement, innovation, and leadership (Phillips, 2003 \& Strahan, 2003).

\subsection{Professional Learning Communities and English Teacher Motivation}

The presence of professional learning communities in an institution like the Hospitality Institute of Sanya has a long way to motivate English teachers. The role of professional learning communities in advancing the teaching styles of English teachers cannot be overemphasized. Professional learning communities' presence increases teachers' interest and motivation in applying new techniques in their class (Johnson, Maddux \& Liu, 2000). The kind of professional teaching communities those teachers belongs to contribute immensely to their motivation. Besides professional learning communities, they are other variables like social or personal factors, socioeconomic status, classroom environment, students' behavior, salaries and incentives, examination stress, and teachers' self-confidence. Alam \& Farid (2011) examined factors that affect teachers' motivational level and found out that majority of the teachers were not happy with their remunerations. The researchers concluded that teachers with low remunerations but the presence of professional learning communities are like to stay in the system, but in a situation where teachers' economic conditions are low, and 
there is no professional learning communities, teachers in such system are not motivated to stay.

\subsection{Hospitality Institute of Sanya}

Hospitality Institute of Sanya is a university college institution in Haitang Bay, Sanya City, Hainan Province of China, with a landmass of over 362 acres and an overall construction area of 140,000 square meters. The institution concentrates on pan-services as a field of study with distinctive characteristics. It offers courses majorly on Hainan's international tourism island construction with a shortage of talents in related fields across China. The six major courses are financial management, hotel management, human resource management, international cruise management, tourism management (online marketing), and western food crafts.

The construction of the Hospitality Institute of Sanya cost one billion four hundred million Chinese yuan. This huge amount of money was born by China Communications Construction, a state-owned enterprise. This China Communications is saddled with the responsibility to do the following: take care of comprehensive protection for student employment, set up a national strategy for the construction of the Hainan International Tourism Island, take care of talent support for the construction of the province's tourism demonstration province, aggressively assume the heavy responsibility of cultivating and transporting practical talents for the society, then fulfill the social responsibility of central enterprises.

In October 2018, the Hospitality Institute of Sanya received the academic certificate of the Lausanne Hotel Management Institute. This makes the institute to become the only institution in China to have done so. This has also made the Hospitality Institute of Sanya become the global Lausanne Hotel Management Institute founded in 1893 and ranks first in the world among hotel management institutions. The institute adheres strictly to people-oriented and follows the construction of the teaching team in a strategic position of priority development of the institution. It has both professors with profound academic accomplishments together with rigorous academic studies, and it also has several young teachers who are energetic and innovative. The institution's unique characteristic is that it attracts a group of senior hotel industry professionals who teach in the institution. (www.isacteach.com).

\subsection{Research Questions}

The following research questions will be answered during the course of the study:

1) What are the magnitudes at which professional learning communities motivate English teacher belief change in Hospitality Institute of Sanya?

2) What are the characteristics of professional learning communities that affect English teacher belief change in Hospitality Institute of Sanya?

3) What are the belief changes experienced by English teachers in Hospitality Institute of Sanya? 


\subsection{Theoretical Framework}

\subsubsection{The Practice Theory}

Practice theory originated from the work of different philosophers and sociologists like Wittgenstein (1958), Taylor (1985), Giddens (1984), and Bourdieu (1990). Although practice theory may not have a unified approach, yet practice theorists have common features: they place practices at the center of understanding; they engage in the specific interest of societal analysis; they observe lifeworld practices of individuals in societal perspectives. The acceptable definition of practice theory was put forward by Lloyd (2010) as the epistemological tradition that focuses on how things get done. This focuses on the ideology that the world operates at the social practices level rather than an individual's attitudes level, behaviors, and choices.

Relevant fields of studies like science and technology, media studies, geography, and design and consumption studies have been using practice theory. Studies like Reid (2011); Kemmis, Wilkinson, Edwards-Groves, Hardy, Grootenboer \& Bristol (2014); Wilkinson \& Kemmis (2015); Brennan (2017) have used practice theory as a theoretical framework to understand or analyze educational issues. Practice theory has contributed to the educational context by providing an alternative to the forms of social theory that categorize individuals as a producer of human behavior (Reid, 2011).

Practice theory works on the assumption that the community or world does not order and construct on the choices, attitudes, or behaviors of individuals but by social practices. Reckwitz (2002) contributed to practice theory with the submission that practices consist of various types of behavior, consisting of different elements connected for people to conform to the routine. These connected elements are forms of bodily activities, 'things' and their use, forms of mental activities, understanding of existing knowledge, know-how, motivational knowledge, and states of emotion. Strengers (2012) believed that individuals' values, attitudes, and beliefs could be cultivated and perceived as arising from within the community or societal practices. It is on this premise that Reckwitz (2002) also submitted that individuals as mentally and bodily agents exhibit the practice through patterns of behaviors that enable people's understanding, desire, and knowing how to conform to the routine.

Nicolini (2012) contributed to practice theory by stating that for an approach to be practice-based, individuals in the community are expected to exhibit certain attributes that will conform to the routine with the use of their bodies, tools, and discourse. From this perspective of Nicolini (2012), the community world seems to be an assemblage of performances made durable by being inscribed in people's minds and bodies, texts, and objects, and attached in a way that will lead to a specific performance being the resource for another performance.

\subsubsection{Practice Theory as a Framework for Professional Learning Communities}

Practices have been defined as an organized constellation of diverse activities of people (Schatzki, 2012). Appropriately, practice theory, therefore, states that practices are enacted through the attributes that are exhibited by individuals but are never simply the attributes that 
are exhibited by an individual. Practices provide meaning-making among a group of individuals in a similar environment, eventually leading to the production and reproduction of ways of interacting, individual identity, and how practices are routinely enacted (Lloyd, 2010). In education, teachers who are teaching in an institution with professional learning communities need to exhibit characteristics that are common to teachers within similar institutional contexts. The teachers in professional learning communities carry out these exhibited characteristics.

Practice as a property of a group is "shaped through histories and traditions that locate practices in such a way that they are 'inherited' already formed, by contemporary practitioners, who in their turn, become custodians and developers of practices" (Lloyd, 2010, p. 250). In this kind of situation, practices emanate from a specific institution are interwoven, formed, and sanctioned through a dialogic intra-group process over time and teachers' individual performances within a specific educational site. In the context of practice theory, teachers are seen as part of an ongoing collective professional learning community.

Nicolini (2012) believed that discourse and practices are made durable through repeated teachers' characters enacted over time. This eventually becomes inscribed in the teachers' objects, bodies, minds, and texts. A social practice theory then sees teachers' practices as the work of professional learning communities in a collaborative manner as a potential structure in the institution's environment. In practice theory, teachers are believed to be carriers of beliefs, values, and attitudes that have become socially acceptable. This means that people in the institution think that teachers' characteristics are the ideal ways of doing things (Feldman \& Fataar, 2014). Therefore, in education, institutions recognize the complexity of teachers' practical understandings as an inter-related element that links teachers' belief change and practices together. Therefore, the professional learning communities hold the potential for pedagogical adaptation and teachers' belief change (Feldman, 2017).

The professional learning communities support the collaborative efforts and ongoing learning among teachers in their institutional contexts that are presented to facilitate conversations between teachers and their institutions. This will enable reflection and belief change among teachers in their institutions. The professional learning communities focus on professional and collaborative teachers' learning with priority to their learning and belief change; therefore, it provides a platform for teachers to learn and support pedagogical change (Lloyd, 2010). Each member of the teachers has the autonomy to make their own decisions, but such decisions are expected to fall within the institution's policy (Lloyd, 2010). Teachers within the professional learning communities of institutions practice as performers of corporeal professional practices through the production of their specific practices (Strengers, 2012). Succinctly, teachers' practices in practice theory are inherently collective, given preference for professional learning communities among English teacher belief changes.

\section{Method}

This study adopted a qualitative research design by using structured interviews to attain deep insights into the impact of professional learning communities on English teacher belief 
change in the Hospitality Institute of Sanya. The population of this study comprised all the ninety-four (94) English teachers in the Hospitality Institute of Sanya.

For a qualitative study such as this type of empirical research work, the most important consideration is determining how many interviews will be necessary to reach the point of saturation whereby an additional interview will not provide any more valuable information. The problem is that there is no scholarly consensus regarding the exact number of interviews for saturation to be reached; Galvin (2015) reviewed 54 qualitative studies that utilized structured interviews and found that 8-17 interviews served as the common range for which majority of the studies felt saturation was attained. In line with this finding, this study decided to conduct (fifteen) 15 interviews for English teachers in the Hospitality Institute of Sanya to ensure that the sample falls within the range of 8-17 in order to ensure that saturation was attained. The (fifteen) 15 English teachers interviewed for this study were selected using the purposive sampling technique. Each respondent must be in the category of English teachers who were willing to participate in the study.

\subsection{Data Collection}

In collecting data for the study, the researcher conducted structured interviews with each of the (fifteen) 15 English teachers for this study, and the following protocols were utilized to ensure that high-quality data was obtained from the participants regarding the three objectives of this study:

1. The interviewer sought to establish rapport with the English teachers by greeting him warmly and asking about their family, and assuring them that the information collected was strictly for academic purposes, with confidentiality confirmed and that it was not for any government purpose.

2. Once consent was received, the interviewer began the interview by asking the following research questions, which served as a guide for the interview:

1) What are the magnitudes at which professional learning communities motivate English teacher belief change in Hospitality Institute of Sanya?

2) What are the characteristics of professional learning communities that affect English teacher belief change in Hospitality Institute of Sanya?

3) What are the belief changes experienced by English teachers in Hospitality Institute of Sanya?

\subsection{Data Analysis}

Thematic analysis was used to analyze the interview data received from the (fifteen) 15 English teachers for this study for each of the three research questions of this study.

\section{Findings}

This section contains findings from the qualitative data collected. It focused on understanding the impact of professional learning communities on English teacher belief change in 
Hospitality Institute of Sanya. Thematic analysis was used to analyze the qualitative data. Whereas, research questions of the study were adopted as the main themes along which the thematic analysis was carried out.

\subsection{Thematic Analysis of the Magnitudes at Which Professional Learning Communities Motivate English Teacher Belief Change}

In order to answer the research question on the magnitudes at which professional learning communities motivate English teacher belief change in Hospitality Institute of Sanya, 15 randomly selected English teachers in Hospitality Institute of Sanya were interviewed, and it was found that the magnitudes at which professional learning communities motivate the belief change of English teachers in Hospitality Institute of Sanya was very high. Beyond these major findings, the majority of the participants had the right perspectives of their communities through the professional learning communities. Participant number thirteen (P13) said that "I thought I understand the people in this institution when I joined them based on what I read and what some friends told me then, but through the membership of professional learning communities, I realized that all my understanding before joining this great institution were all myths." The majority of the participants were on the same wavelength as P13. As for P1, "I was motivated to learn more about the culture of not only the members of staff but also the students in Hospitality Institute of Sanya." This view was similar to the views of P2 to P6, P8 to P7, and P9 to P4. P6 added that "my beliefs about the region have not been changed, but professional learning communities have really changed my belief when it comes to the people in the region. "However, $\mathrm{P} 9$ was not too motivated by professional learning communities; he said, "I learn a lot of things from the professional learning communities, I also learn more about the people in the community, but these communities had not changed my earlier beliefs." All the participants agreed that professional learning communities had motivated them in one way or the other.

\subsection{Thematic Analysis of the Characteristics of Professional Learning Communities That Affect English Teacher Belief Change}

To answer the research question on the characteristics of professional learning communities that affect English teacher belief change in Hospitality Institute of Sanya, 15 randomly selected English teachers were interviewed in Hospitality Institute of Sanya, and the following characteristics of professional learning communities were found out. According to P3, "Reflective dialog is one of the characteristics of professional learning communities that has changed my belief in this institution. There is an avenue for teachers to engage one another in professional dialog on any issues, be it personal or educational issues.". P12 added that, "Regarding reflective dialog, I have learned a lot of things that I may not have time to read." Ten participants were all on the same wavelength with P3 and P12.

Regarding characteristics of professional learning communities, P3 said that "Feedback is one of the characteristics of professional learning communities that have changed my belief in this institution. Feedback among teachers after meetings has always been a sense of information for me as a foreign language teacher. My belief in the teaching method has seriously been increased as a result of professional learning communities". P4 said, "I do receive feedback 
from members anytime I missed meetings in a professional learning community." Only two participants were on the same wavelength with $\mathrm{P} 4$, while 11 participants were all on the same wavelength with P3.

In the words of P2, who said, "Collaborative activity is the main characteristics of professional learning communities that have changed my belief in this institution. I have made some requests through the professional learning communities, requests that were difficult for a single teacher to achieve have been achieved with the function of professional learning communities". Most of the participants were on the same wavelength with P2, except a few (which are P1, P3, and P9) who recognized the collaborative effort of professional learning communities. Still, they have not benefitted from the collaborative activity.

Still, on characteristics of professional learning communities, P6 said, "Shared sense of purpose is the best characteristics of professional learning communities that have changed my belief in this institution, by sharing a sense of purpose, my belief about the mission of the institution has changed over time. There was a time when I believe that the principles that operate in this institution were not ideal, but with a shared sense of purpose, I was able to have the right perspective". P9 said that "of all the professional learning communities that I have experienced, the one in this institution has given me more avenue for a shared sense of purpose and this has increased my perspective about Hospitality Institute of Sanya." Several participants were on the same wavelength with P6 and P9, except (P1, P2, and P13) who recognized the opportunity of a shared sense of purpose, but they always preferred to remain silent and observe the present situation most times.

Lastly, on characteristics of professional learning communities, P7 said, "I used to believe that my commitment to students' successes was enough until professional learning communities opened my eyes to collective focus on students' learning, and that was when I appreciated the role of the collective commitment of teachers their students' success". P12 said that "collective focus on students is no doubt makes the task of international language teacher very easy, the reason is that attention of one teacher at a time is always different. This collective focus on students' learning helps both the teachers and learners of international language". All the participants who responded to the role of characteristics of professional learning communities were on the same wavelength with P7 and P12.

\subsection{Thematic Analysis of the Belief Changes Experienced by English Teachers}

To evaluate the belief changes experienced by English teachers in the Hospitality Institute of Sanya, 15 randomly selected water English teachers were interviewed in the Hospitality Institute of Sanya. The following belief changes were found out. According to P5, "In Hospitality Institute of Sanya, one of the belief changes that I have experienced as English teachers was the rate at which students learn a foreign language here. Going by the nature of their original language, which does not have anything to do with the English alphabets, I used to believe that they will find it difficult to cope. There are some international languages that are similar when you look at French and English, but there is no similarity between the Chinese language and the English language. The students of the English language in this institution proved me wrong.". $\mathrm{P} 8, \mathrm{P} 12, \mathrm{P} 9$, and $\mathrm{P} 3$ came from the same direction as $\mathrm{P} 5$. 


\section{MInstitute Macrothink $_{\text {Int }}$}

International Journal of Linguistics

ISSN 1948-5425

2021, Vol. 13, No. 3

Still, on English teachers' belief changes, P15 said, "The belief change that I have experienced in this institution as English teachers were the cognition of foreign English language teachers. Initially, my opinion was that Chinese language letters were highly voluminous and cumbersome. As a foreign English language teacher, I had little or no interest in the language unless those keywords facilitate teaching and learning. Still, as time passed, I realized that I have master the nitty-gritty of not only the letters but also the Chinese language". Some participants like P2, P9, P12, P7, P3, and P10 were in line with P15.

Lastly, on English teachers' belief changes, P8, P11, P15, P3, P7, P2, P5, and P9 had all experienced English teachers' belief changes in teachers' pedagogy. In the words of P13, "The belief changes that I as an English language teacher have experienced in Hospitality Institute of Sanya was on teaching pedagogy. There are different techniques that English teachers can use when teaching, but when it comes to teaching with the English language, it is a whole new ball game entirely".

Table 1. Summary of findings of the thematic analysis

\begin{tabular}{|c|c|c|}
\hline $\mathbf{S} / \mathbf{N}$ & THEME & FINDINGS \\
\hline 1 & $\begin{array}{l}\text { Magnitudes at which } \\
\text { professional learning } \\
\text { communities motivate } \\
\text { English teacher belief } \\
\text { change }\end{array}$ & $\begin{array}{l}\text { The magnitudes at which professional learning communities } \\
\text { motivate English teacher belief change in Hospitality Institute of } \\
\text { Sanya was very high in the following ways: } \\
\text { Understanding of the people in Hospitality Institute of Sanya. } \\
\text { () Culture of the people in Hospitality Institute of Sanya. } \\
\text { i) Learn more about the people in the community. }\end{array}$ \\
\hline 2 & $\begin{array}{l}\text { Characteristics of } \\
\text { professional learning } \\
\text { communities that affect } \\
\text { English teacher belief } \\
\text { change }\end{array}$ & $\begin{array}{l}\text { The following characteristics of professional learning communities } \\
\text { were found out to have effect on English teacher belief change: } \\
\text { ) Reflective dialog. } \\
\text { () Feedback among teachers. } \\
\text { i) Collaborative activity. } \\
\text {.) Shared sense of purpose. } \\
\text { i) Collective focus on students' learning. }\end{array}$ \\
\hline 3 & $\begin{array}{l}\text { The belief changes } \\
\text { experienced by English } \\
\text { teachers }\end{array}$ & $\begin{array}{l}\text { The following belief changes were found out among English } \\
\text { teacher in Hospitality Institute of Sanya: } \\
\text { The rate at which students learn foreign language. } \\
\text { ') The cognition of foreign English language teachers. } \\
\text { i) English teachers' pedagogy. }\end{array}$ \\
\hline
\end{tabular}

5. Discussion

One of the research questions answered in this study was, "What are the magnitudes at which professional learning communities motivate English teacher belief change in Hospitality Institute of Sanya?" The result from the finding revealed that the magnitudes at which professional learning communities motivate English teacher belief change in Hospitality Institute of Sanya was very high. Professional learning communities have motivated English teacher belief change by learning more about the people in the community through the culture of the people and understanding of the people in the Hospitality Institute of Sanya. This 
indicates that most of the participants had the right perspectives of their communities through the professional learning communities. This finding is in agreement with the findings of Akerson, Cullen, \& Hanson (2009); Lee (2004); Hollins, McIntyre, DeBose, Hollins \& Towner (2004); Turner et al. (2011); Brodie \& Borko (2016).

Akerson, Cullen, \& Hanson (2009) identified the mastery of the subject matter as one factor that brings about changes in teachers' beliefs and teachers' practices. Lee (2004) identified teaching as one factor that brings about changes in teachers' beliefs and teachers' practices. Hollins, McIntyre, DeBose, Hollins \& Towner (2004) identified learning as one factor that brings about changes in teachers' beliefs and teachers' practices. In contrast, Turner et al. (2011) identified motivation and instruction as major factors that bring about changes in teachers' beliefs and teachers' practices. Brodie \& Borko (2016) found out that learning is a fundamental part of professional learning communities. Acquisition of learning in new and relevant knowledge makes teachers move from a collective and reflective inquiry into better professional teachers. This enables teachers to justify their decisions, thinking, and actions in agreement with their knowledge base.

The second research question answered in this study was, "What are the characteristics of professional learning communities that affect English teacher belief change in Hospitality Institute of Sanya?" The finding revealed that reflective dialog, feedback among teachers, collaborative activity, a shared sense of purpose, and collective focus on students' learning were the major characteristics of professional learning communities that affected English teacher belief change in Hospitality Institute of Sanya. This indicates that belief changes in English teachers are being affected by the characteristics of professional learning communities. This is in line with the findings of Meirink, Meijer, Verloop, \& Bergen (2009); Hoekstra, Brekelmans, Beijaard, \& Korthagen (2009); Turner et al. (2011). These researchers categorized characteristics of professional learning communities that lead to teacher change into two: the first category was referred to as shared goals (collective focus on student learning and a shared sense of purpose). The second category was referred to as learning activities (feedback on instruction, reflective dialog, and collaborative activity).

Lastly, research question three answered in this study, "What are the belief changes experienced by English teachers in the Hospitality Institute of Sanya?" The finding revealed the rate at which students learn a foreign language, foreign English teachers' cognitions, and English teachers' pedagogies as the belief changes among English teachers in Hospitality Institute of Sanya. This indicates that English teachers experienced different belief changes in the Hospitality Institute of Sanya. This is in agreement with the findings of Fullan (2007); Feldman (2017). Fullan (2007) found out that teachers' cognition ability to acquire knowledge and teachers' beliefs are powerful cognitive filters. Feldman (2017) found out that institutions recognized the complexity of teachers' practical understandings as an inter-related element that links teachers' belief change and practices together.

\section{Conclusion and Implications}

This study has investigated the impact of professional learning communities on English teacher belief change using English teachers in Hospitality Institute of Sanya as a case study. This 
study has shed light on the concept of professional learning communities, English teacher belief change, the Hospitality Institute of Sanya, theoretical framework, and relevant methodology. A qualitative approach that interviewed (fifteen) 15 English teachers in the Hospitality Institute of Sanya was used in this study.

This study's findings have provided insights into the impact of professional learning communities on English teacher belief change in Hospitality Institute of Sanya. The findings show most participants had the right perspectives of their communities through the professional learning communities, which exert positive effects on English teacher belief change. Reflective dialog, feedback among teachers, collaborative activity, a shared sense of purpose, and collective focus on students' learning were the major characteristics of professional learning communities that affected English teacher belief change in Hospitality Institute of Sanya. The rate at which students learn a foreign language, foreign English teachers' cognitions, and English teachers' pedagogies were found out as the belief changes among English teachers in Hospitality Institute of Sanya.

The study's findings advance the practice theory that collaborates effective professional learning communities on English teacher belief change in different perspectives in Hospitality Institute of Sanya. Since English teachers play significant roles in the Hospitality Institute of Sanya, there is a need for a conducive change process in their beliefs. Therefore, this study suggests that the English teacher belief change should be complemented with observations that will verify the data.

This study's findings are significant to the English teachers and the institution and other future researchers. In an institution like Hospitality Institute of Sanya, teacher belief change needs to be monitored by the authority of the institution, going by the nature of the activities that go on in the institution; however, this study reveals that professional learning communities nurture the learning and growth of English teacher belief change.

There is no doubt that this study is a single case study in Hospitality Institute of Sanya, only a minimal contribution towards more considerable goal attainment of the society and the body of knowledge. By the nature of its limitation to only one institution, its findings may be regarded as restricted and tentative, which is subject to change over a period of time. For a more comprehensive understanding of the role of professional learning communities on teacher belief change, the researcher therefore strongly suggests that more studies be carried out on studies that cut cross-case in different departments or institutions to make for the deficiencies of this study, and more importantly, to validate the findings of this study.

\section{References}

Akerson, V. L., Cullen, T. A., \& Hanson, D. L. (2009). Fostering a community of practice through a professional development program to improve elementary teachers' views of nature of science and teaching practice. Journal of Research in Science Teaching, 46, 1090-1113. https://doi.org/10.1002/tea.20303

Alam, T. A., \& Farid, S. (2011). Factors affecting teachers motivation. International Journal of Business and Social Science, 2(1). 
Andrews, D., \& Lewis, M. (2002). The experience of a professional community: Teachers developing a new image of themselves and their workplace. Educational Research, 44, 237-254. https://doi.org/10.1080/00131880210135340

Beck, J., Czerniak, C. M., \& Lumpe, A. T. (2000). An exploratory study of teachers' beliefs regarding the implementation of constructivism in their classrooms. Journal of Science Teacher Education, 11, 323-343. https://doi.org/10.1023/A:1009481115135

Borg, S. (2003). Teacher cognition in language teaching: A review of research on what language teachers think, know, believe, and do. Language Teaching, 36, 81-109. https://doi.org/10.1017/S0261444803001903

Bourdieu, P. (1990). The logic of practice. Stanford, CA: Stanford University Press.

Brennan, M. (2017). Struggles for teacher education in the age of the Anthropocene. Journal of Education, 69, 43-66.

Brodie, K., \& Borko, H. (2016). Professional learning communities in South African schools and teacher education programmes. Cape Town, South Africa: HSRC Press.

Bulkley, K. E., \& Hicks, J. (2005). Managing community: Professional community in charter schools operated by educational management organizations. Educational Administration Quarterly, 41(2), 306-348. https://doi.org/10.1177/0013161X04269594

Calderhead, J. (1996). Teachers: Beliefs and knowledge. In D. C. Berliner, \& R. C. Calfee (Eds.), Handbook of educational psychology (pp. 709-725). New York, NY: Macmillan.

Clark, C. M., \& Peterson, P. L. (1986). Teachers' thought processes. In M. C. Wittrock (Ed.), Handbook of research on teaching (3rd ed., pp. 255-296). New York, NY: Macmillan.

Clarke, D., \& Hollingsworth, H. (2002). Elaborating a model of teacher professional growth. $\begin{array}{llll}\text { Teaching } \quad \text { and } & \text { Teacher } & \text { 9ducation, } & \text { 18, }\end{array}$ https://doi.org/10.1016/S0742-051X(02)00053-7

Darling-Hammond, L. (2013). Diversity, equity, and education in a globalized world. Kappa Delta Pi Record, 49(3), 113-115. https://doi.org/10.1080/00228958.2013.819186

Feldman, J. (2017). The role of professional learning communities in facilitating teachers' pedagogical adaptation and change. Journal of Education, 67, 65-82.

Feldman, J., \& Fataar, A. (2014). Conceptualising the setting up of a professional learning community for teachers' pedagogical learning. South African Journal of Higher Education, 28(5), 1525-1540.

Fernandez, C. (2002). Learning from Japanese Approaches to Professional Development: The Case of Lesson Study. Journal of Teacher Education, 53(5), 393-405. https://doi.org/10.1177/002248702237394

Fullan, M. (2007). The new meaning of educational change (4th ed.). New York, NY: Teacher College Press. 


\section{Macrothink}

International Journal of Linguistics

ISSN 1948-5425

2021, Vol. 13, No. 3

Galvin, R. (2015). How many interviews are enough? Do qualitative interviews in building energy consumption research produce reliable knowledge?. Journal of Building Engineering, 1, 2-12. https://doi.org/10.1016/j.jobe.2014.12.001

Giddens, A. (1984). The constitution of society: Outline of the theory of structuration. Cambridge, England: Polity Press.

Grossman, P., Wineburg, S., \& Woolworth, S. (2001). Toward a theory of teacher community. Teachers College Record, 103, 942-1012. https://doi.org/10.1111/0161-4681.00140

Guskey, T. R. (2002). Professional development and teacher change. Teachers and Teaching: Theory and Practice, 8, 381-391. https://doi.org/10.1080/135406002100000512

Harris, A., \& Jones, M. (2010). Professional learning communities and system improvement. Improving Schools, 13, 172-181. https://doi.org/10.1177/1365480210376487

Head, K., \& Taylor, P. (1997). Readings in teacher development. Oxford: Heinemann English Language Teaching.

Hindin, A., Morocco, C. C., Mott, E. A., \& Aguilar, C. M. (2007). More than just a group: Teacher collaboration and learning in the workplace. Teachers and Teaching: Theory and Practice, 13, 349-376. https://doi.org/10.1080/13540600701391911

Hoekstra, A., Brekelmans, M., Beijaard, D., \& Korthagen, F. (2009). Experienced teachers' informal learning: Learning activities and changes in behavior and cognition. Teaching and Teacher Education, 25, 663-673. https://doi.org/10.1016/j.tate.2008.12.007

Hollins, E. R., McIntyre, L. R., DeBose, C., Hollins, K. S., \& Towner, A. (2004). Promoting a self-sustaining learning community: Investigating an internal model for teacher development. International Journal of Qualitative Studies in Education, 17, 247-264. https://doi.org/10.1080/09518390310001653899

Hord, S. M., Roussin, J. L., \& Sommers, W. A. (2009). Guiding professional learning communities: Inspiration, challenge, surprise, and meaning. Thousand Oaks, CA: Corwin Press. Retrievd from https://www.isacteach.com/university/hospitality-institute-of-sanya/

Hunzicker, J. (2004). The beliefs-behavior connection: Leading teachers toward change. Principal, 84, 44-46.

Johnson, D. L., Maddux, C. D., \& Liu, L. (2000). Integration of technology into the classroom: Case studies. Binghamton, NY: the Haworth Press. https://doi.org/10.1300/J025v16n02_01

Kaasila, R., \& Lauriala, A. (2010). Towards a collaborative, interactionist model of teacher change. Teaching and Teacher Education, 26, 854-862. https://doi.org/10.1016/j.tate.2009.10.023

Kagan, D. M. (1992). Implication of research on teacher belief. Educational Psychologist, 27, 65-90. https://doi.org/10.1207/s15326985ep2701_6 
Kemmis, S., Wilkinson, J., Edwards-Groves, C., Hardy, I., Grootenboer, P., \& Bristol, L. (2014). Changing practices, changing education. Singapore: Springer. https://doi.org/10.1007/978-981-4560-47-4

Kruse, S. D., Louis, K. S., \& Bryk, A. S. (1995). An emerging framework for analyzing school-based professional community. In K. S. Louis, \& S. D. Kruse (Eds.), Professionalism and community: Perspectives on reforming urban schools (pp. 23-34). Thousand Oaks, CA: Corwin Press.

Lave, J., \& Wenger, E. (1991). Situated learning: Legitimate peripheral participation. New York, NY: Cambridge University Press. https://doi.org/10.1017/CBO9780511815355

Lee, O. (2004). Teacher change in beliefs and practices in science and literacy instruction with English language learners. Journal of Research in Science Teaching, 41, 65-93. https://doi.org/10.1002/tea.10125

Little, J. W. (2003). Inside teacher community: Representations of classroom practice. Teachers College Record, 105, 913-945. https://doi.org/10.1111/1467-9620.00273

Lloyd, A. (2010). Framing information literacy as information practice: Site ontology and practice theory. Journal of Documentation, 66(2), 245-258. https://doi.org/10.1108/00220411011023643

Louis, K. S., \& Marks, H. M. (1998). Does professional community affect the classroom? Teachers' work and student experiences in restructuring schools. American Journal of Education, 106, 532-574. https://doi.org/10.1086/444197

Maloney, C., \& Konza, D. (2011). A case study of teachers' professional learning: Becoming a community of professional learning or not?. Issues in Educational Research, 21, 75-87.

McLaughlin, M. W., \& Talbert, J. E. (2006). Building school-based teacher learning communities. New York, NY: Teachers College Press.

McLaughlin, M., \& Talbert, J. (2001). Professional communities and the work of high school teaching. Chicago, IL: University of Chicago Press.

Meirink, J. A., Meijer, P. C., Verloop, N., \& Bergen, T. C. M. (2009). Understanding teacher learning in secondary education: The relations of teacher activities to changed beliefs about teaching and learning. Teaching and Teacher Education, 25, 89-100. https://doi.org/10.1016/j.tate.2008.07.003

Nicolini, D. (2012). Practice theory, work, and organization: An introduction. Oxford, England: Oxford University Press.

Pajares, M. F. (1992). Teachers' beliefs and educational research: Cleaning up a messy construct. Review of Educational Research, 62, 307-332. https://doi.org/10.3102/00346543062003307

Phillips, J. (2003). Powerful learning: Creating learning communities in urban school reform. Journal of Curriculum and Supervision, 18, 240-258. 
Reckwitz, A. (2002). Toward a theory of social practices: A development in culturalist theorizing. European Journal of Social Theory, 5(2), 243-263. https://doi.org/10.1177/13684310222225432

Reid, J. A. (2011). A practice turn for teacher education?. Asia-Pacific Journal of Teacher Education, 39(4), 293-310. https://doi.org/10.1080/1359866X.2011.614688

Richardson, V. (1996). The role of attitudes and beliefs in learning to teach. In J. Sikula, T. Buttery, \& E. Guyton (Eds.), Handbook of research on teacher education (2nd ed., pp. 102-117). New York, NY: Macmillan.

Richardson, V., \& Placier, P. (2001). Teacher change. In V. Richardson (Ed.), Handbook of research on teaching (4th ed., pp. 877-904). Washington, DC: American Educational Research Association.

Roberts, S. M., \& Pruitt, E. Z. (2008). Schools as professional learning communities: Collaborative activities and strategies for professional development. Corwin Press.

Schatzki, T. R. (2012). A primer on practices: Theory and research. In J. Higgs, R. Barnett, S. Billet, M. Hutchings, \& F. Trede (Eds.), Practice-based education: Perspectives and strategies. Rotterdam, The Netherlands: Sense.

Scribner, J. P., Cockrell, K. S., Cockrell, D. H., \& Valentine, J. W. (1999). Creating professional communities in schools through organizational learning: An evaluation of a school improvement process. Educational Administration Quarterly, 35(1), 130-160. https://doi.org/10.1177/0013161X99351007

Stoll, L., \& K Seashore Louis, K. (2007). Professional learning communities: divergence, depth and dilemmas.

Stoll, L., Bolam, R., McMahon, A., Wallace, M., \& Thomas, S. (2006). Professional learning communities: a review of the literature. Journal of Educational Change, 7, 221-258. https://doi.org/10.1007/s10833-006-0001-8

Strahan, D. (2003). Promoting a collaborative professional culture in three elementary schools that have beaten the odds. The Elementary School Journal, 104, 127-146. https://doi.org/10.1086/499746

Strengers, Y. (2012). Peak electricity demand and social practice theories: Reframing the role of change agents in the energy sector. Energy Policy, 44, 226-234. https://doi.org/10.1016/j.enpol.2012.01.046

Tam, A. C. F. (2010a). Understanding the shaping of teachers' teaching beliefs and behaviours through their learning experiences: Case studies [in Chinese]. Contemporary Educational Research Quarterly, 18, 71-111. https://doi.org/10.1080/13632434.2010.497480

Tam, A. C. F. (2010b). Understanding the leadership qualities of a head of department coping with curriculum changes in a Hong Kong secondary school. School Leadership \& Management, 30, 367-386. 


\section{I Macrothink}

International Journal of Linguistics

ISSN 1948-5425

2021, Vol. 13, No. 3

Tam, A. C. F. (2011). The development of an effective teacher learning community: A case study of Hong Kong [in Chinese]. Journal of Educational Research and Development, 7, 213-246.

Tam, A. C. F. (2012). Teachers' misconceptions and questionable practices when using Putonghua as the medium-of-instruction: A case study of Hong Kong. Teachers and Teaching: Theory and Practice, 18, 655-673. https://doi.org/10.1080/13540602.2012.746500

Tam, A. C. F. (2014). The role of a professional learning community in teacher change: a perspective from beliefs and practices, teachers and teaching: theory and practice. https://doi.org/10.1080/13540602.2014.928122

Tam, C. F. (2005). Teaching beliefs of Chinese language teachers and their influence on curriculum implementation [in Chinese]. Unpublished EdD dissertation. Faculty of Education, The Chinese University of Hong Kong.

Taylor, C. (1985). Philosophy and the human sciences: Philosophical papers 2. Cambridge, England: Cambridge University Press. https://doi.org/10.1017/CBO9781139173490

Turner, J. C., Warzon, K. B., \& Christensen, A. (2011). Motivating mathematics learning: Changes in teachers' practices and beliefs during a nine-month collaboration. American Educational Research Journal, 48, 718-762. https://doi.org/10.3102/0002831210385103

Vescio, V., Ross, D., \& Adams, A. (2008). A review of research on the impact of professional learning communities on teaching practice and student learning. Teaching and Teacher Education, 24, 80-91. https://doi.org/10.1016/j.tate.2007.01.004

Wilkinson, J., \& Kemmis, S. (2015). Practice theory: Viewing leadership as leading. Educational Philosophy and Theory, 47(4), 342-358. https://doi.org/10.1080/00131857.2014.976928

Wittgenstein, L. (1958). Philosophical investigations, Translated by GEM Anscombe. Oxford, England: Blackwell.

Wong, J. L. N. (2010). Searching for good practice in teaching: A comparison of two subject-based professional learning communities in a secondary school in Shanghai. Compare: A Journal of Comparative and International Education, 40, 623-639. https://doi.org/10.1080/03057920903553308

\section{Copyrights}

Copyright for this article is retained by the author(s), with first publication rights granted to the journal.

This is an open-access article distributed under the terms and conditions of the Creative Commons Attribution license (http://creativecommons.org/licenses/by/4.0/) 